\title{
The Effects of Aqueous Extracts of Acalypha wilkesiana Supplementation and Exercise Training on Hematopoietic System in Rats
}

\author{
Alfred F. Ehiaghe ${ }^{1,2}$, Joy I. Ehiaghe ${ }^{2}$, Igere E. Bright ${ }^{2,3}$, Iyen I. Roland ${ }^{2}$ \\ ${ }^{1}$ Department of Haematology, Igbinedion University, Okada, Nigeria; ${ }^{2}$ Department of Microbiology, Lahor Research Centre, Benin \\ City, Nigeria; ${ }^{3}$ Department of Microbiology and Biotechnology, Western Delta University, Oghara, Nigeria. \\ Email: fredleo2547@yahoo.com
}

Received June $14^{\text {th }}, 2013$; revised July $14^{\text {th }}, 2013$; accepted August $15^{\text {th }}, 2013$

Copyright (C) 2013 Alfred F. Ehiaghe et al. This is an open access article distributed under the Creative Commons Attribution License, which permits unrestricted use, distribution, and reproduction in any medium, provided the original work is properly cited.

\begin{abstract}
The aim of this study is to compare the effects of single and combined oral administration of fresh aqueous extracts of Acalypha wilkesiana supplementation at $300 \mathrm{mg} / \mathrm{ml}$ and exercise training on some immuno indicator parameters in Rats. The study was carried out in the College of Health Sciences, Department of Hematology, Igbinedion University, Okada between the Month of June and July, 2012. Following 30 days post-oral administration of extracts on (Group 2 and Group 3), exercise training on (Group 2 and Group 4) and No treated on Group 1, hematological parameters were determined using the sysmex ${ }^{\circledR}$ Automated Hematological Analyzer, while CD4 and CD8 cells were estimated using Partec cyflow counter and serum IgG is determined using the ELISA Method. CD4 cells, CD8, and Total WBC count show a statistically significant increase while $\mathrm{Hb}$ concentration and $\mathrm{IgG}$ level show a statistically significant decrease in Group 2 and Group $4(\mathrm{P}<0.05)$. Total WBC count shows a statistically significant increase against the control Group, while CD4 cell, CD8 cell count, Hb-concentration and IgG level show a statistically insignificant increase (P>0.05), Table 2. Acalypha wilkesiana at a concentration of $300 \mathrm{mg} / \mathrm{g} /$ day seems to be immuno-protective in Rats. Single or combine effects of prolonged exercise and $A$. wilkesiana produce significant change in some immuno indicators parameters. However, the molecular mechanism behind their combined effect would require further investigation.
\end{abstract}

Keywords: Acalypha Wilkesian; Serum IgG; ELISA; CD4 Cells; CD8 Cells; Exercise

\section{Introduction}

Acalypha wilkesiana is an evergreen Shrub. It grows $3 \mathrm{~m}$ high and $2 \mathrm{~m}$ across. The leaves are coppery green with red splashes of colour, its other names including: $A$. amentaceae and $A$. tricolor. Its common names are copper leaf, Joseph's coat, fire dragon and match-me-if-you-can [1]. The Hausas of the Northern Nigeria call it "Jiwene", while the Yoruba of the Southern Nigeria call it "aworoso". It is propagated by stem cutting at anytime of the year $[1,2]$.

The phytochemical screening of the leave revealed the presence of Alkaloids, Carotenoids, Flavonoids, Proteins, Lipid, Carbohydrate, Reducing sugar, fiber, Saponins and Tannins, all of which have potential health promoting effects $[3,4]$. The expressed juice of A. wilkesiana is used as an antimicrobial agent for the treatment of gastrointestinal disorders and fungal skin infection [5]. In the southern Nigeria, the leaves extracts are used for the management of hypertension [6]. Its Beta carotene contents act as an antioxidant, which helps to boost the immune system against cancer, cataract and damaging effects of radiation $[3,7]$.

The immune system has a central role in protecting against various external disease promoting factors and perhaps against malignant cells. The immune system regulates itself by means of the helper and suppressor $\mathrm{T}$ cells. Nutrients and other constituents of Medicinal plants play a contributory role in enhancing immune function [8].

Exercise is any bodily activity that enhances physical fitness [9]. It improves mental health, helps prevent depression and promote positive self-esteem [10] and reduces the level of cortisol which suppresses the immune system [11]. Physical exercises are generally grouped into three types, which include, flexibility exercise (such as stretching, which improves the range of motion on the muscle and joints), Aerobic exercise (such as cycling, 
swimming, walking, skipping rope, running, biking or playing tennis, which focus on increasing cardiovascular endurance) and Anaerobic exercise (such as weight training or sprinting, which increases short-term strength [1214].

The aim of this study is to compare the effect(s) of single and combined oral administration of fresh aqueous extract of A. wilkesiana supplementation at $300 \mathrm{mg} / \mathrm{ml}$ concentration and exercise training on CD4 cell count, Immunoglobulin $\mathrm{G}(\operatorname{IgG})$ level, Total White Blood cell count and Hemoglobin concentration in Rats.

\section{Materials and Methods}

\subsection{Study Area}

This study was carried out in the college of Health Sciences, Department of Hematology, Igbinedion University, Okada, located in Ovia-North East Local Government area of Edo State, coordinates: $6^{\circ} 300 \mathrm{E}$ in Central Southern Nigeria between the month of May and July, 2012. Predominant occupation among the people is farming, despite the availability of reliable medical service, the local populaces still rely on the use of herbs as medicines for both curative and prophylaxis purpose.

\subsection{Sample Size}

The sample size was calculated using the formula described by [15]

where:

$$
\mathrm{E}=\mathrm{N}-\mathrm{B}-\mathrm{T}
$$

$\mathrm{N}=$ The minimum number of unit in the study (Minus one);

$\mathrm{T}=$ The treatment component including control group (Minus one);

$\mathrm{B}=$ The Blocking component, representing environmental effect allowed for the design (minus one) $\mathrm{B}=0$;

$\mathrm{E}=$ The degree of freedom (Between 10 and 20).

Using the formula, where $\mathrm{E}=20, \mathrm{~B}=0, \mathrm{~T}=4$.

The minimum number of sample size will be 23 .

\subsection{Study Design}

A total of 24 male albino Rats weighing $105 \pm 05 \mathrm{~g}$ was purchased from the Animal production and Health Department, Federal University of Technology, Akure, Ondo State, Nigeria and housed in the experimental Animal House, College of Health Science, Department of Hematology, Igbinedion University Okada, Separately in well ventilated wire-bottom steel cage under hygienic condition with proper aeration at $25^{\circ} \mathrm{C} \pm 2{ }^{\circ} \mathrm{C}$ and a relative humidity of $45 \%-50 \%$. The Rats were randomly assigned into 4 groups of 6 rats each and fed on standard Rat diet (10 g/100 g body weight) twice daily and tap water ad libitum. Prior to commencement of administration of the extract and exercise training, the Rats were allowed to stabilize in the Animal House with standard 12 hours light dark cycle, for a period of 14 days and was treated for 30 days. All studies on the experimental animals were conducted in accordance with the current Animal Care Regulations and standards approved by the Institute for Laboratory Animal Research. The Rats were marked by ear puncturing system [16].

\subsection{Collection and Preparation of Crude Aqueous Extracts}

Samples of fresh leaves of $A$. wilkesiana were collected from within the college of Health Science, Igbinedion University, Okada. After due identification at the Igbinedion University Herbarium, the leaves were washed thoroughly in tap and sterile distilled water. $30 \mathrm{~g}$ of the washed leaves were soaked for 24 hours and homogenized in a clean electric blender containing $100 \mathrm{ml}$ sterile distilled water according to the method [17]. These gave a $3.0 \mathrm{~g} / 10 \mathrm{ml}=300 \mathrm{mg} / \mathrm{ml}$ of the homogenate. The homogenates was shaken for one hour in a rotary flask and then filter into separate sterile container using a funnel containing sterile cotton wool and later with Whatman No. 1 filter paper. The liquid filtrates were transferred into separate sterile MacCartney bottles and stored in the refrigerator at $4^{\circ} \mathrm{C}$ after daily administration to the experimental animals.

\subsection{Animal Treatment}

A total of 24 Rats were randomly assigned into 4 groups (6 per group) and treated as shown in Table 1.

G2 and G3 were given $1 \mathrm{ml} / 100 \mathrm{~g}$ body weight of the extract using intragastric tube and adjusted daily with change in body weight throughout the treatment period which lasted for 30 days. G2 and G4 were simultaneously trained with exercise preconditioning in the form of mere swimming. The swimming exercise was performed in a $120 \mathrm{~cm}$ deep $\times 80 \mathrm{~cm}$ wide cylindrical tank, with water temperature of $31^{\circ} \mathrm{C} \pm 1^{\circ} \mathrm{C}$. Swimming was

Table 1. Showing the mode of exercise and aqueous extract administration to the subjects.

\begin{tabular}{ccc}
\hline GROUPS & EXERCISE & $\begin{array}{c}\text { AQUEOUS EXTRACT } \\
\text { OF A. wilkesiana }\end{array}$ \\
\hline G1(n=6) & NO & NO \\
G2(n=6) & YES & $300 \mathrm{mg} / \mathrm{g} /$ day \\
G3(n=6) & NO & $300 \mathrm{mg} / \mathrm{g} /$ day \\
G4(n=6) & YES & NO \\
\hline
\end{tabular}

$\mathrm{G} 1=$ Control group (No extract \& No Exercise); G2 = $300 \mathrm{mg} / \mathrm{g} / \mathrm{day}$ extracts and exercise; $\mathrm{G} 3=300 \mathrm{mg} / \mathrm{g} /$ day extract; G4 = Exercise only 
performed for 6 weeks, 5 days per week and one hour per day as described [18].

\subsection{Euthanasia}

Overnight prior to euthanasia (Mercy death); the animals were starved of food. The animals were sacrificed by cervical dislocation as described [19]. Cardiac blood specimens were obtained from each Rat by terminal bleeding from the heart. The first half of the blood collected was transferred into total white blood cell, Hemoglobin concentration and CD4 cell evaluation. While the second portion was transferred into an anticoagulant free test tube and allowed to clot and subsequently centrifuged at $750 \times \mathrm{g}$ for 15 minutes to obtain serum.

The serum were immediately aliquoted into Eppendorf tubes placed on ice and immediately stored at $-80^{\circ} \mathrm{C}$ until serum immunoglobulin $\mathrm{G}$ ( $\operatorname{IgG}$ ) is evaluated using Enzyme Linked Immunosorbent Assay Method.

\subsection{Evaluation of Parameters}

Hematological parameters (Total white Blood cells and Hemoglobin Concentration) were determined using the sysmex $^{\circledR}$ Automated Hematology Analyzer Kx-2IN, sysmex corporation, Kobe-Japan. It employs WBC detector block and $\mathrm{WBC} / \mathrm{HGB}$ lyse reagent to measure WBC count and Hemoglobin concentration as described [20].

CD4 and CD8 cell count were estimated using Partec Cyflow Counter, Germany for the quantification of CD4 $\mathrm{T}$ lymphocytes as described [21].

Serum immunoglobin G (IgG) level was assayed by conventional Sandwich Enzyme Linked Immunosorbent Assay (ELISA) using 96 well plates coated with antibody specific for IgG (Pharmacia CAP system IgG FEIA, Pharmacia, Uppsala, Sweden). The assay system utilizes two unique antibodies (a mouse monoclonal and a goat polyclonal) directed against distinct antigenic determinants on the IgG molecule. Into the plastic micro titer well with anti-IgG (Mouse monoclonal) was added test sample/control containing IgG to form immune com- plexes. Anti-IgG (goat polyclonal Enzyme-labeled with horseradish peroxidase was added to each well and incubated for 45 minutes at room temperature. The IgG molecule in the sample was sandwiched between the solid phase and enzyme-labeled antibodies. The wells were emptied and washed five times to remove unbound-labeled antibody an enzyme chromogen was added to the wells incubated for 15 minutes at room temperature in the dark, resulting in the development of a blue colour. A stop solution was added to each well and the intensity of the developed yellow colour is directly proportional to the concentration of $\operatorname{IgG}$ in the sample. This was read at $450 \mathrm{~nm}$ wavelength. Awareness Technology Inc. Palm City FL 34991, USA.

\section{Statistical Analysis}

All numerical results were obtained from the four (4) group (control and treated). Data were presented as mean \pm Standard Deviation and Analyzed using one way analysis of variance (ANOVA) and Tukey-Kramer Multiple Comparisons Test Using SPSS-18.0 (Statistical packages for social scientist-version 18.0) statistical program. $\mathrm{P}$ values $<0.05$ were considered significant

\section{Results}

Our findings revealed that CD4 cells count, CD8 cells counts, total WBC count shows statistically significant increase while $\mathrm{Hb}$ concentration and IgG level shows a statistical significant decreased in Group 2 and Group 4 against the control group (G1). In Group 3, the total WBC count shows a statistically significant increase against control group (G1) while CD4 cell count, CD8 cell count, $\mathrm{Hb}$-Concentration and IgG level shows a statistically insignificant increase against the control group $(\mathrm{P}>0.05)$, Table 2.

\section{Discussion}

Our study revealed that administration of $300 \mathrm{mg} / \mathrm{ml}$ of $A$. wilkesiana to experimental animal shows a statistically

Table 2. Showing the mean \pm standard deviation of parameters analyzed in each group.

\begin{tabular}{|c|c|c|c|c|}
\hline Groups Parameters & G1 & G2 & G3 & G4 \\
\hline CD4 cells $($ Cells/ $\mu 1)$ & $600 \pm 0.02$ & $650 \pm 0.03^{\mathrm{S}}$ & $601 \pm 0.02^{\mathrm{NS}}$ & $650 \pm 0.04^{\mathrm{S}}$ \\
\hline CD8 cells $($ Cells/ $\mu 1)$ & $300 \pm 0.01$ & $500 \pm 0.04^{\mathrm{S}}$ & $301 \pm 0.01^{\mathrm{NS}}$ & $450 \pm 0.03^{\mathrm{S}}$ \\
\hline Total WBC (Cells/ $\mu \mathrm{l})$ & $5000 \pm 1.4$ & $8000 \pm 0.9^{\mathrm{S}}$ & $5300 \pm 0.6^{\mathrm{S}}$ & $7500 \pm 0.7^{\mathrm{S}}$ \\
\hline Hb.Conc. (g/dl) & $8.0 \pm 0.3$ & $7.5 \pm 0.01^{\mathrm{s}}$ & $8.2 \pm 0.02^{\mathrm{NS}}$ & $7.0 \pm 0.02^{\mathrm{S}}$ \\
\hline $\operatorname{IgG}(\mathrm{mg} / \mathrm{dl})$ & $1400 \pm 0.2$ & $800 \pm 0.04^{\mathrm{S}}$ & $1405 \pm 0.8^{\mathrm{NS}}$ & $650 \pm 0.4^{\mathrm{S}}$ \\
\hline
\end{tabular}

All values are expressed as Mean \pm Standard deviation of the 6 animals in each group. Keys: WBC $=$ White Blood cell; Hb. Conc. $=$ Hemoglobin concentration; $\mathrm{IgG}=$ Immunoglobulin G; G1 = Control group (No extract \& No Exercise); G2 = $300 \mathrm{mg} / \mathrm{g} / \mathrm{d}$ extracts and exercise; G3 = $300 \mathrm{mg} / \mathrm{g} / \mathrm{d}$ extract; G4 = Exercise only; $\mathrm{S}=\mathrm{P}<0.05 ; \mathrm{NS}=\mathrm{P}>0.05$. 
insignificant alteration in CD4, CD8, Total WBC, $\mathrm{Hb}$ and $\operatorname{IgG}$ level, Table 2. This may be due to the fact that at a concentration of $300 \mathrm{mg} / \mathrm{ml}$, the extract seems to have some immuno protective effects or non toxic effects on the indicator parameters. This is in line with these findings. Its Beta Carotene contents acts as an antioxidant, which help to boost the immune system against cancer, cataract and damaging effects of radiation $[3,7]$. The expressed juices of the extract are used as an antimicrobial agent for the treatment of infection [5].

As seen in Table 2, the increase in TWBC after the bout of exercise with or without the extracts may be due to an adaptive mechanisms by the immune system to remove the damaged tissue caused by the prolong exercise in the experimental animal. This had been reported by these authors. The immune system response to the damage done by exercise peak 2 to 7 days after exercise, which is the period during which most of the adaptation that lead to greater fitness occurs, this effect may be to some extent protective against diseases which are associated with oxidative stress and provides partial explanation for the lower incidence of major diseases and better health for those who undertake regular exercise [22,23]. The Leucocytosis is due to Neutrophilia and the recruitment of B and T cells to the peripheral blood after acute moderate exercise [24].

In Table 2, the fall in the CD4/CD8 ratio may be due to the transient change in the lymphocyte subset, which favours the proliferation of the CD8, which are involved in the cytotoxic mediated cellular immune response. This is in accordance with these findings. The fall in CD4/ CD8 ratio is mainly due to an increase in the number of CD8 T cells, the change in the lymphocyte subsets is transient, basal level usually being reached within one and half hour after exercise [25].

Table 2 shows a decrease in the level of immunoglobulin $\mathrm{G}(\mathrm{IgG})$ after the exercise with or without the aqueous extract of A. wilkesiana may be due to the immuno suppressive effects of the increase production of cortisol occasioned by the stress response during exercising to exhaustion. This has been reported by these Authors. Glucocorticoids (cortisol) are potent modulators of the immune system with immunosuppressive effects [26]. Several stressors (exercise) have been associated with a shift in cytokine production toward the anti-inflammatory pattern with Glucocorticoids as the proposed mediators of this shift [26].

At diagnosis, the mean hemoglobin concentration shows a statistically significant reduction in G2 and G4 against the control group (G1), Table 2. This might be due to the oxidative stress induced by the prolong exercise on the matured red blood cells of the experimental animals. This is in accordance with these findings. A decreased in the
Hemoglobin concentration is majorly due to Oxidative damage to the red blood cells arising from an imbalance between reactive oxygen species production and antioxidant level. Factors such as decreased in red cell survival and reduced erythropoietin response by the bone marrow erythroid cell can induce anemia $[27,28]$.

\section{Conclusion}

A. wilkesiana at a concentration of $300 \mathrm{mg} / \mathrm{g} /$ day seems to be immuno-protective in Rats. But the single or combine effects of prolonged exercise and A. wilkesiana produce significant change in some immuno indicators parameters. The immune system is merely responding to the damage done by the exercise bout, during which most of the adaptation leads to greater fitness, if balance diet and proper resting are observed after exercise. But the molecular mechanism behind their combined effect would require further investigation.

\section{REFERENCES}

[1] S. Christman, "Alalypha Wilkesiana Floridata.com LC, Florida," 2004.

Http/www.floridata.Com/ref/Asalpha wil.cfm

[2] E. F. Ciliman, Acalypha Wilkesiana Environmental Horticulture Department, Florida Cooperative Extension Service, Institute of Food and Agricultural Sciences, University of Florida, Fact Sheet FPS, 1999.

[3] S. K. Basil, J. E. Thomas and S. N. Acharya, "Prospects for Growth in Global Nutraceutical and Functional Food Markets: A Canadian Perspective," Austral Journal of Basil Applied Science, Vol. 1, No. 4, 2007, pp. 637-649. http:/www.insinet.net/ajbas/637-649.Pdf

[4] AOAC (Association of Official Analytical Chemists), "Official Method of Analysis of the AOAC," 18th Edition, Association of Official Analytical Chemists, Washington DC, 2006.

[5] A. O. Ogundaini, "From Greens into Medicine: Taking a Lead from Nature," In: Inaugural Lecture Series 176, OAU Press Limited, Ile-Ife, 2005, pp. 12-15. http:/www.oauife.edu.ng/faculties/ pharmacy.aogund.pdf

[6] J. C. Ikewuchi, A. Anyadiegwu, E. V. Ugono and S. O. Okungbowa, "Effect of Acalypha Wilkesiana on Plasma Sodium and Potassium Concentration of Normal Rabbits," Pakistan Jorunal of Nutrition, Vol. 7, No. 1, 2008, pp. 130-132. doi:10.3923/pjn.2008.130.132

[7] B. Best, "Phytochemical as Nutraceutical," 2006. http//www.benbest.com/ nutreut/phytochemical.html

[8] O. M. Kandil, T. H. Abdellah and A. Elkhadi, "Garlic and the Immune System in Humans: Its Effects on Natural Killer Cells," Federal Procedures, Vol. 46, 1987, p. 441.

[9] M. J. Stampfer, F. B. Hu, J. E. Manson, E. B. Rimm and W. C. Willet, "Primary prevention of Coronary Heart Disease in Women through Diet and Lifestyle," New England Jorunal of Medicine, Vol. 343, No. 1, 2000, pp. 16- 


\section{2. doi:10.1056/NEJM200007063430103}

[10] F. B. Hu, J. Manson, M. Stampfer and C. Graham, "Diet, Lifestyle and Risk of Type 2 Diabetes Mellitus in Women," New England Journal of Medicine, Vol. 345, No. 11, 2001, pp. 790-797. doi:10.1056/NEJMoa010492

[11] A. Cornil, G. Decoster and J. Copinschi, "Effects of Muscular Exercise on the Plasma Level of Cortisol in Man," European Journal of Endocrinology, Vol. 10, 1965, pp. 60-63.

[12] O. O'Connor, M. Crowe and W. Spinks, "Effects of Static Stretching on Leg Capacity during Cycling," Turin, Vol. 46, No. 1, 2005, pp. 52-56.

[13] J. Wilmore and H. Knittgen, "Aerobic Exercise and Endurance Improving Fitness for Health Benefits," The Physician and Sports Medicine, Vol. 31, No. 5, 2003, p. 45. doi:10.3810/psm.2003.05.367

[14] N. De Vos, N. Singh, D. Ross and T. Stavrines, "Optimal Load for Increasing Muscle Power during Explosive Resistance Training on Older Adults," The Journals of Gerontology, Vol. 60A, No. 5, 2005, pp. 638-647.

[15] J. Kirkwood and H. Robert, "The UFAW Handbook on the Care and Management of Laboratory and Other Research Animal," Wiley, Blackwell, 2010, p. 29.

[16] Institute for Laboratory Animal Research Council, "Guide for the Care and Use of Laboratory Animals," 8th Edition, Institute for Laboratory Animal Research Council, Division on Earth and Life Studies, American Academy of Sciences, National Research Council of the National Academics. The National Academies Press, Washington DC, 1996, pp. 11-31.

[17] A. Sofowora, "Medicinal Plants and Traditional Medicine in Africa," John Wiley, Chichester, 1982, p. 179.

[18] M. Hashemi, M. Bayat, A. R. Azizi-Saraji and M. Enterzari, "The Effects of Swimming Exercise on Experimental Diabetic Myopathy in Rats," World Journal of Zoology, Vol. 4, No. 3, 2009, pp. 216-222.

[19] J. Ochei and A. Kolhatkar, "Methods of Euthanasia," In: J. Ochei and A. Kolhatkar, Eds., Medical Laboratory Science, Theory and Practice, McGraw-Hill Publishing Company Limited, New Delhi, 2006, p. 1221.
[20] O. I. Samuel, N. Thomas, O. U. Ernest, N. N. Imelda, N. S. Elvis and E. Ifeyinwa, "Comparison of Hematological Parameters Determined by the Sysmex KX-2IN Automated Hematology Analyzer and the Manual Count," BMC Clinical Pathology, Vol. 10, 2006, pp. 3-5. doi:10.1186/1472-6890-10-3

[21] Partec Cyflow Counter (PCC), "Typical Steps of Particle Analysis Using Partec Cyflow Counter," Instrument Operating Manual, Partec GmbH OHO-Hann-str 32, Munster, 2010, pp. 5-8.

[22] P. Tiidus, "Radical Species in Inflammation and Overtraining," Canadian Journal of Pharmacology, Vol. 76, No. 6, 1998, pp. 533-538. doi:10.1139/y98-047

[23] C. Leeuwenburgh and J. Heinecke, "Oxidative Stress and Antioxidants in Exercises," Curriculum of Medical Chemistry, Vol. 8, No. 7, 2007, pp. 829-838.

[24] D. C. Nieman, S. L. Nehlsen-Cannarella and K. M. Donohue, "The Effect of Acute Moderate Exercise on Leukocyte and lymphocyte Subpopulation," Medical Science Sport Exercise, Vol. 22, 1991, pp. 578-585.

[25] B. K. Pedersen, N. Tvede and F. R. Hansin, "Modulation of Natural Killer Cell Activitity in Peripheral Blood by Physical Exercise," Scandinavian Journal of Immunology, Vol. 72, 1998, pp. 673-678.

[26] E. Elinav, G. Pinsker, R. Safadi, O. Pappo, M. Bromberg and E. Anis, "Association between Consumption of Herbalife-Nutritional Supplements and Acute Hepatotoxicity," Journal of Hepatology, Vol. 47, No. 4, 2007, pp. 514-520. doi:10.1016/j.jhep.2007.06.016

[27] F. A. Ehiaghe, I. J. Ehiaghe, S. T. Aladenika, S. M. O. Etikerentse, A. I. Ikusemoro, B. H. Oladeinde, E. O. Osakue, S. S. Enitan and J. K. Fadairo, "The Characteristics of Pulmonary Tuberculosis amongst Patients Attending Chest Clinic, Including Age, Sex, Occupation and Hemoglobin Concentration in Benin City, Nigeria," Open Journal of Clinical Diagnostics, Vol. 3, 2013, pp. 14-18. doi:10.4236/ojcd.2013.31004

[28] O. Ebrahim, P. I. Folb and J. P. Robson, "Blunted Erythropoietin Response to Anemia in Tuberculosis," European Journal of Hematology, Vol. 55, No. 4, 1995, pp. 251-254. doi:10.1111/j.1600-0609.1995.tb00267.x 